\title{
"Ajattele maailmanlaajuisesti, toimi paikallisesti" (J. G. Granö). Maantieteen termistön kehittäminen 1920-luvun Virossa ja Suomessa
}

\author{
PÄIVI LAINE, EVE MIKONE
}

Turun yliopisto

Tiivistelmä. Artikkeli selvittää maantieteen termistön kehittämistä Virossa ja Suomessa 1920-luvulla. Suomalainen maantieteilijä J. G. Granö tuli 1919 Tarttoon perustamaan maantieteen oppituolia. Tämä oli ylipäänsä ensimmäinen kerta, kun maantiedettä alettiin opettaa viroksi, ja hän tarvitsi valtavasti uutta termistöä. Lyhyen Viron-kautensa aikana Granö pyrki luomaan vironkielisen tieteellisen termijärjestelmän ja vahvistamaan opiskelijoiden käsitystä maantieteestä tieteenalana. Hän piti tärkeänä erikoisalan omakielisen termistön hallintaa. Pyrimme hahmottamaan hajanaisesta arkisto- ja sanastoaineistosta esimerkkejä Granön luomista vironkielisistä termeistä. Oletamme, että J. V. Veskin nimiin kirjatut uudistermit eivät kaikki ole J. V. Veskin luomia vaan termistöjen kehittämiseen osallistuivat myös erikoisalojen asiantuntijat. Kun Granö palasi Suomeen, hän jatkoi termijärjestelmän ja erityisesti maisemamaantieteen kuvausjärjestelmän kehittämistä. Hänen teoreettinen pääteoksensa Puhdas maantiede (1930) yhdistää Virossa ja Suomessa luodut termit ja kuvaustavat. Hän korosti työssään tieteen tekemistä kansallisilla kielillä mutta tulosten tiedottamista myös kansainvälisillä kielillä.

Avainsanat: termistön kehittäminen; kirjakieli; tieteen kieli 
"ajattele maAilmanlaajuisesti, tolmi paikallisesti" (J. g. granö)

\section{Aluksi}

Tarkastelemme artikkelissamme tieteen kielen ja etenkin termistön kehittymistä Virossa ja Suomessa. Haluamme kiinnittää huomiota siihen, että vaikutteet saattoivat joissakin tapauksissa tulla viron kielestä suomeen eikä vain suomesta viroon, kuten virolaisen tutkimuksen perusteella voisi ajatella. Esittelemme esimerkkinä maantieteilijä Johannes Gabriel Granön sanastotyötä Virossa ja lopuksi hahmottelemme vaikutteita, joita hän toi Virosta Suomeen. Aineiston erikoisluonteen vuoksi on määrällistä analyysiä oleellisempaa keskittyä termijärjestelmän kehittämiseen ja luotujen termien kuvaamiseen. Pyrimme luonnehtimaan termistöjä ja niissä näkyviä yhtäläisyyksiä ja eroja. Kuvaamme lyhyesti kirjakielten kehittämisen lähtökohtia, koska ne ovat Suomessa ja Virossa olleet historian vuoksi erilaisia. Toiseksi käsittelemme ajanjaksoa, jolloin Virossa syntyi nopeasti tarve kehittää vain kotikielenä ja kansakouluissa käytetystä virosta sivistyskieli. Apuna siinä olivat monet suomalaiset tutkijat.

Tieteen kielen ja yliopisto-opetuksen suomen- ja vironkielistäminen tapahtuivat melko samaan aikaan. Kun Tarton yliopisto päätettiin Viron itsenäistymisen aikoihin vironkielistää, apuun pyydettiin professoreita Suomesta. Tarttoon lähtivät esimerkiksi ensimmäinen viron ja itämerensuomalaisten kielten professori Lauri Kettunen, etnologian professori ja Viron Kansallismuseon perustaja Ilmari Manninen sekä matematiikan professori Kalle Väisälä. Yksi ensimmäisenä Tarttoon lähteneistä suomalaisista professoreista oli Granö, joka saapui Tarttoon 1919 luomaan vironkielistä maantieteen oppituolia (esim. Tiitta 2011: 215).

Tarkastelemme Granön työtä kielitieteilijöinä ja termistön kehittymisen näkökulmista, sillä tutkimus on aiemmin keskittynyt pääasiassa vain hänen ansioihinsa maantieteilijänä. Varsinkin vironkielisen maantieteen termistön kehittämistä ja Granön osuutta siinä on kuvattu niukasti. Granön työ havainnollistaa sitä, miten kansalliset kielet valjastettiin tieteen käyttöön. Hänen elämäntyönsä punaisena lankana oli kansallisen ja kansainvälisen tutkimuksen yhdistäminen: Granöstä 
tutkimusta piti tehdä kansallisilla kielillä mutta tulokset tuli esittää myös kansainvälisillä kielillä (Tiitta 2011: 214; Tommila 2012).

\section{Kielellinen lähtötilanne Suomessa ja Virossa}

1800-luvun lopussa ja 1900-luvun alussa virolla ja suomella oli kielinä varsin erilainen asema, vaikka kumpaakin maata hallitsi Venäjä. Suomessa Venäjä pyrki heikentämään ruotsin kielen statusta ja vahvistamaan samalla suomen kielen käyttöä. Kansallismielisten ajatusten pelossa suomeksi julkaisemista kuitenkin rajoitettiin sensuuriasetuksilla (ks. esim. Häkkinen 1994: 50-52). Virossa puolestaan oli käynnissä venäläistäminen, joka vaikutti erityisesti koulutusjärjestelmään, ja viron kielen asema heikkeni entisestään (ks. esim. Raag 2008: 83-84).

Suomessa alettiin jo 1820-70-luvuilla aktiivisesti rakentaa kirjakieltä, jota voitiin käyttää yhteisenä sivistyskielenä ja jossa oli vähän alueellista vaihtelua (Nordlund 2004: 290-291). Silloin luotiin sanastollisen demokratian perusta, koska käsitteiden nimityksiä sepitettiin kansankielen aineksista (esim. Hakulinen 1979: 428; Pokela 2004: 22). Keskustelu kirjakielen ohjailusta oli jo silloin vilkasta, ja osallistujilla oli vahvoja näkemyksiä kirjakielen kehittämisen periaatteista: toiset kannattivat kieliopillisuuskantaa, toiset kansankielisyyskantaa ja kolmannet lähinnä purismia (esim. Nordlund 2004: 296). 1800-luvun aikana saatiin kehitettyä kattava yleissanasto, ja vuosisadan vaihteessa uudissanat käsittivät lähinnä erikoisalojen termejä. Merkittäviksi uudissanojen sepittäjiksi kielitieteilijöiden rinnalle tulivat eri tieteenalojen asiantuntijat. (Esim. Pulkkinen 1972: 48; Pokela 2004: 24.)

Virossa oltiin 1800-luvun alussa vielä tilanteessa, jossa kirjakielen kehittämisen päähuomio oli kahden kirjakielen (tallinnan ja tarton kirjakielten) yhdistämisessä ja uuden kirjakielen yhdenmukaistamisessa. Kirjakieltä kehitettiin ensi kertaa talonpojille ja heille tarkoitettuja julkaisuja (kalenterit, ohjeistukset jne.) varten. Sitä ennen viron kirjakieltä oli jalostettu saksalaiselle papistolle ja uskonnollisten tekstien julkaisemiseen (Kask 1970: 176-177). Vironkielisen termistön 
"ajattele maailmanlaajuisesti, toimi paikallisesti" ( J. g. granö)

luomistarpeeseen kiinnitettiin huomiota vasta kansallisen heräämisen aikana 1800-luvun lopulla. Vuoden 1879 Viron Kirjamiesten Seuran (Eesti Kirjameeste Selts) kokouksen pöytäkirjassa on päätös siitä, että viron kirjakieltä pitää rikastaa ja tieteen termistöä kehittää. Neuvona oli mallin ottaminen suomen kielestä. (Kask 1938.) Termistön kehittämisen tarve korostuu Virossa uudelleen 1900-luvun alussa. Keskustelua käytiin varsinkin oppikirjojen edistämisen haasteista, koska ilmaisut olivat kömpelöitä ja epätarkkoja. Termeinä käytettiin kielen tavallisia ilmauksia, esimerkiksi hulkujad, kolijad ja paigalasuvad rahvad 'maleksijat, muuttajat ja paikoillaan pysyvät kansat', pea-ilmakaared ja kõrvalised kaared 'pääilmansuunnat ja sivulliset suunnat' (Veski, A. 1996: 109).

Suomessa sanastonkehitystä ja kielenohjailua hallitsi purismi 1900luvun alusta 1950-luvulle saakka (esim. Rintala 2000: 20). Erityisesti vierastettiin murteellisuuksia ja muukalaisuuksia (Paunonen 1989: 211212). Purismin taustalla oli aatteellinen ajatus puhtaasta suomen kielestä ja tavoitteena oli suomen kielen puhdistaminen. (Kolehmainen 2014: 70.) Kansainvälistä kulttuurisanastoa pyrittiin luomaan tai kääntämään suomeksi (Pokela 2004: 52). Suomessa kirjakielen voimakkain kehityskausi oli jo 1800-luvulla ja 1900-luvun alussa elettiin jo melko seesteistä nykysuomen aikaa.

Viron kirjakielen kehityksessä tapahtui vuosina 1887-1923 valtava ilmaisukyvyn joustavuuden ja tarkkuuden loikka (Saareste 1938: 33). Monet tahot (Eesti Kirjameeste Selts, Keelekonverentsid, sanomalehdet) olivat kiinnittäneet huomiota viron kirjakielessä esiintyneeseen kieliopilliseen ja leksikaaliseen kirjavuuteen sekä sivistyskielessä tarvittavan sanaston vajavaisuuteen. Viron kirjakielen edistämisen eteen käytyjen keskustelujen ja toiminnan aktiivisuus oli 1900-luvun alussa täysin omaa luokkaansa. Kielitieteilijöiden lisäksi keskusteluun osallistuivat aktiivisesti myös kansalaiset, ja kielenuudistus näytti olevan lähes kaikkien mielessä. Tilannetta kuvaa varsin osuvasti tapahtuma murretutkija Andrus Saaresten elämästä. Kun hän halusi Viron Vapaussodan jälkeen (1920) mennä murteenkeruumatkalle Virumaalle, hän haki asekantolupaa, koska alueella esiintyi vielä rikollisuutta. Tarton poliisilaitoksessa 
kysyttiin Saarestelta, mihin hän asetta tarvitsi. Saareste vastasi "Keeleuurimisel" 'kielentutkimukseen'. Kun hän pari päivä myöhemmin sai luvan, siinä luki "[---] luba välja antud brauningu kandmiseks. Otstarve: keeleuuendus" '[---] lupa myönnetty brauningin kantamiseen. Käyttötarkoitus: kielen uudistaminen'. (Saareste 1951: 56.)

\section{Revoluutio ja evoluutio - kirjakielen kehitystyö Virossa 1900-luvun alussa}

Vuonna 1919, kun J. G. Granö saapui Tarttoon, hänelle oli tavallaan pöytä katettuna. Granön mielessä oli maantieteen itsenäistäminen omaksi tieteenalakseen ja sen vapauttaminen muiden tieteiden sivuhaaran statuksesta (Granö 1920). Tähän liittyi uuden järjestelmän luominen, ja sen kuvaamiseen tarvittiin systemaattinen termistö. Periaatteet, miten ja millaisista aineksista uusia termejä kieleen luotiin, olivat melko valmiina konseptina odottamassa Virossa. Granö oli Tarton yliopistoon tullessaan nuori maantieteilijä ja täynnä intoa uusien ideoiden soveltamiseen. Järjestelmällisen termistön luojaksi ja kehittäjäksi hän jalostui Tartossa.

Virossa väittelivät ja täydensivät toisiaan kaksi kirjakielen kehittämiseen tähtäävää koulukuntaa: keeleuuendus 'kielen uudistaminen' ja keelekorrladus 'kielen huolto'. Johannes Aavik, joka tunnetaan kielen uudistamisen johtohahmona, aloitti räjähdysmäisen valistustyön vuonna 1912, jolloin häneltä ilmestyi 29 artikkelia viron kielen kehittämisestä (Raag 2008: 145). Aavik oli väsymätön visionääri, jolla oli omat näkemyksensä kielen muuttamisesta kulttuurikieleksi. Aavikille kieli oli ihmisen käyttämä väline, jonka jalostamisessa olivat tärkeitä käytännöllisyys, kauneus ja ainutlaatuisuus. Aavik toivoi nopeata vallankumousta. Hänelle kielen käytännöllisyys tarkoitti kielen rikkautta (sanaston runsautta), ilmausten selkeyttä ja tarkkuutta (vältetään homonyymejä), lyhyyttä, mukavuutta, helposti opittavuutta ja omaksuttavuutta. Kielen kauneus tarkoitti sitä, että vältetään "rumien sointujen" aiheuttajien käyttämistä ja perussanojen suosimista yhdyssanojen 
"ajattele maAilmanlaajuisesti, tolmi paikallisesti" (J. g. granö)

sijaan. Kielen ainutlaatuisuus tarkoitti kielihistoriallisten seikkojen huomioimista, murresanojen ja suomalaista alkuperää olevien sanojen suosimista ja vierassanojen välttämistä. (Esim. Erelt 2002: 74-91; Raag 2008: 146-147.)

Kielen huoltoa ja hidasta evoluutiota puolsi toinen viron kirjakielen kehittämisen suurhahmo Johannes Voldemar Veski. Koska J. V. Veski oli taustaltaan luonnontieteilijä, hänelle kaikki kaikessa oli järjestelmä ja järjestelmällisyys. Hänen mukaansa kaikki kielen kehitykseen tarvittavat elementit olivat viron kielessä jo olemassa, niihin piti vain paremmin tutustua ja ottaa ne määrätietoisesti käyttöön. Termistön kehittämiseen sopivat kummankin koulukunnan näkemykset: J. V. Veskin korostamat järjestelmä ja järjestelmällisyys, Aavikin peräänkuuluttamat käytännöllisyys, ilmausten selkeys ja tarkkuus (homonyymien välttäminen), lyhyys, mukavuus, helposti opittavuus ja omaksuttavuus.

Granö kävi varmasti henkilökohtaisia keskusteluja J. V. Veskin kanssa ja tunsi hänen periaatteensa, mutta yhtä lailla on todennäköistä, että hän oli hyvin tietoinen myös Johannes Aavikin vallankumouksellisista periaatteista. Aavik julkaisi 1920-luvulla niin paljon, että hänen artikkelinsa eivät voineet jäädä huomaamatta. Kuten muun muassa Tiiu Erelt (2002) on korostanut, Aavik ja J. V. Veski eivät taistelleet kielen kehitysrintaman vastakkaisilla puolilla, vaan monessa asiassa kävi niin, että idean, jonka Aavik esitti, vahvisti käyttöön J. V. Veski. Granö näyttääkin yhdistävän hämmästyttävän saumattomasti maantieteen termistön kehittämistarpeet ja kielenohjailun periaatteet, joista Virossa ja Suomessa käytiin keskustelua.

\section{J. G. Granön viron kielen taito}

J. G. Granö (1882-1956) aloitti maantieteilijän uransa Helsingin yliopistossa, josta hän siirtyi pian Tarttoon. Tarton kauden jälkeen Granö työskenteli Helsingin ja Turun yliopistoissa. Hän kehitti maisemamaantieteen tutkimustradition ja teki useita tutkimusmatkoja muun muassa Siperiaan ja Mongoliaan (Kant 1956: 254-257). 
Granön viron kielen taidosta on esitetty varsin varovaisia arvioita, lähinnä sellaisia, että hän osasi viroa jonkin verran ja saatuaan viran Tartosta hän aloitti aktiiviset viron kielen opinnot (Tiitta 2011: 213). Viro ja viron kieli eivät olleet Granölle vieraita, koska hän oli lapsuudessaan asunut kuusi vuotta Siperiassa suomalais-virolaisessa kylässä, jossa suomalaisetkin puhuivat viroa. Granön isä toimi kylässä pappina. (Tiitta 2011:27-28.) Lisäksi Granöllä oli nuoruudessaan useita virolaisia ystäviä, tunnetuin heistä oli Karl Vokk, joka toimi avustajana Granön tutkimusmatkoilla (Kurs 1995: 1058).

Käsityksemme mukaan Granön viron kielen taidon on pitänyt olla erinomaista jo heti silloin, kun hän siirtyi vuonna 1919 opettamaan Tarttoon. Hän aloitti saman tien kartografian kurssin, jonka työkielinä olivat viro, saksa ja venäjä. Huomionarvoista on, että viron lisäksi käytettiin muita kieliä, muttei suinkaan Granön vähäisen viron taidon vuoksi, vaan sen vuoksi, että virolaiset opiskelijat eivät hallinneet alansa vironkielistä sanastoa. Tammikuussa 1920 Granö luennoi maisemamaantieteen kurssin vain viroksi (Tammekann 1932; Kurs 1995: 1059). Vironkielisten luentojen lisäksi Granö alkoi luoda ja opettaa vironkielistä terminologiaa. Viron Kirjallisuuden Seura oli julkaissut vironkielisen maantieteen sanaston 1911, mutta termistö oli vanhentunut ja suppea. Granön johtama ammattisanaston lautakunta aloitti työskentelyn jo vuonna 1920.

Granön oppilaita Tartossa olivat muun muassa Jaan Rumma, August Tammekann ja Edgar Kant (Kurs 1995). Edgar Kant auttoi maantieteen sanaston kokoamisessa ja oli kiinnostunut termeistä myös myöhemmin (Tiitta 2011: 223). Sanastotyön lisäksi Granö käynnisti Virossa laajan kotiseutututkimushankkeen ja toimitti yhdessä Jaan Rumman ja J. V. Veskin kanssa Tartumaa-maakuntateoksen (Rumma ym.1925), joka oli tutkimustyön ensimmäinen osa. Myös muita osia toimittivat Granön oppilaat, esimerkiksi Edgar Kant (1926). Erillisten sanastojen lisäksi maantieteen termejä esiteltiin ja vakiinnutettiin maakuntateosten ja oppikirjojen hakemistoissa (esim. Vilberg 1921).

Maakuntateosten valmistelutyötä edelsivät Granön pitämät Tarton yliopiston maantieteen seminaarit. Maisemamaantieteen kurssin jatkona 
"ajattele maAilmanlaajuisesti, tolmi paikallisesti" (J. g. granö)

opiskelijat suorittivat kesällä 1920 ensimmäisen yliopistomaantieteen välityöharjoituksen. Viro oli jaettu eri alueisiin, ja syksyllä 1920 opiskelijat esittivät maakunnistaan tieteelliset kuvaukset (Kurs 1995: 1059). Granön erinomaisesta viron kielen taidosta kertovat seminaarien pöytäkirjat, joita säilytetään Tarton yliopiston maantieteen oppiaineessa ${ }^{1}$. Seminaarien pöytäkirjoihin on kirjattu opponentin lyhyt arvio työstä, opiskelijoiden kommentteja ja jokaisen työn kohdalla myös professori Granön kommentit.

Seuraavassa on esimerkkejä Granön huomioista (suom. E. M.):

1) "Kõnes oli öeldud: "tasandik seljandikkega", kuid see ei ole mitte kohane, sest mõlemad on ise mõisted. Geoloog võiks seda ütleda, kuid geograaf mitte, metoodiliselt ei oleks see mitte täpipäälne. Õigem on tarvitada lausikmaa."

'Puheessa on sanottu: "tasanko harjanteineen", mutta tämä ei ole soveliasta, koska molemmat ovat eri käsitteitä. Geologi voisi näin sanoa muttei geografi, metodisesti tämä ei olisi tarkka. Oikeampaa on käyttää aukeamaa.'

2) "Internationaal nimetuste asemel tuleks eestikeelseid tarvitada." 'kansainvälisten nimitysten sijaan tulisi käyttää vironkielisiä.

3) "[Granö] soovitab tarvitada siinkohal mõiste tasandik asemel lausmaa"

'[Granö] suosittelee tässä termin tasandik sijaan käytettäväksi lausmaa?.

"Professor juhib tähelepanu veel selle pääle, et ei ole tarvitatud komisjoni poolt välja töötatud sõnu."

'Professori kiinnittää huomiota siihen, ettei ole käytetty lautakunnan työstämiä sanoja'.

4) "randjärv oli võõras alpmägestikus, peab olema vist rantjärv s.o. äärjärv.”

'rantajärvi oli outo alppivuoristossa, pitäisi kai olla kanttijärvi s.o. reunajärvi'.

Kiitokset aineistosta tutkija Taavi Paelle. 
5) "Ka keelelisi puudusi leidub referaadis, näitukseks mõne rea pro mõne sõna."

'Referaatissa on myös kielellisiä virheitä, esim. muutaman rivin pro muutaman sanan.'

Näistä Granön kommenteista nähdään, miten pikkutarkka hän oli vironkielisen termistön ja viron kielen suhteen. Vironkieliselläkin kestää hetken, ennen kuin hän ymmärtää randjärv ja rantjärv -sanojen eron. Granö ruoti vierasperäisten sanojen käyttöä ja viron tyylillisiä seikkoja varsin tarkkaan ja noudatti vastaavia periaatteita myös palattuaan Suomeen, koska hän pyrki luomaan erityisesti omakielistä termistöä.

Vuonna 1920 Granö julkaisi vironkielisen artikkelin Geograafia kui teadus ja ülikooli aine (Maantiede tieteenä ja yliopiston oppiaineena). Tässä artikkelissa Granö määrittää maantieteen sisällön ja rajaa pois muita tieteenaloja (geologia, petrografia, meteorologia, antropologia ja etnografia). Teoreettinen rajanveto pohjustaa myös tulevaa maantieteen termistön kehitystyötä. Mitä ilmeisimmin Granö on kirjoittanut artikkelin itse viroksi, eikä se ole kenenkään virolaisen kääntämä. Ott Kurs (1995: 1062) huomauttaa, että kenttätöiden muistiinpanot Granö on tehnyt omaan muistivihkoonsa myös viroksi.

\section{J. G. Granön maantieteen termistötyö Virossa}

Viron itsenäistymisen jälkeen (1918) viron kielen asema muuttui hyvin radikaalisti. Virosta tuli valtion kansallinen kieli (riigikeel). Yliopiston luennoille ja tieteellisten artikkeleiden kirjoittamiseen tarvittiin kipeästi eri alojen termistöjä. Yliopistosta tuli luontevasti keskus, jossa aloittivat työnsä eri tieteenalojen sanastojen kehittämisen lautakunnat.

Maantieteen termistön lautakunta aloitti toimintansa vuonna 1920, ja sen koollekutsujana sekä johtohahmona toimi Granö. Samaan aikaan aloittivat toimintansa monen muun tieteenalan termistön kehittämisen lautakunnat. Tieteenalan asiantuntijoiden lisäksi kaikkiin lautakuntiin kuului viron kielen asiantuntijana J. V. Veski (Kask 1938). 
"ajattele maAilmanlaajuisesti, tolmi paikallisesti" (J. g. granö)

Jonain kummallisena historiallisena oikkuna virolaiset kielitieteilijät ovat lähteneet siitä, että kaikki 1920-30-lukujen termistöt olisivat J. V. Veskin tuotosta (ks. Kask 1938; Veski, A. 1996). Arnold Kask on laskenut, että vuosina 1918-1938 J. V. Veski olisi päivätyön ohella työskennellyt sanastolautakunnissa yhteensä noin 890 työpäivää eli 2,5 vuotta. Näin hän olisi luonut viroon noin 130000 termiä. (Kask 1938.) J. V. Veskin päätoimi oli silloin Tarton yliopiston viron kielen lehtorina, ja lisäksi hän laati kolmiosaisen suurteoksen Eesti õigekeelsuse sõnaraamat (Peegel 1963: 4). Tämän perusteella päättelemme, että on varsin epätodennäköistä, että J. V. Veski olisi pystynyt päävelvoitteidensa ohella paneutumaan yksityiskohtaisesti todella monen eri tieteenalan sisältöön ja luomaan niille tarvittavaa termistöä. Hän toimi todennäköisesti kieliasiantuntijana, joka neuvoi lautakuntia yleisten periaatteiden ja linjojen hahmottamisessa ja kertoi mielipiteensä, jos jotain konkreettisesti kysyttiin.

Virolaiset maantieteilijät ovat eri yhteyksissä esittäneet useat maantieteen termit Granön luomiksi tai maantieteen erityismerkitykseen täsmentämiksi². Edgar Kant, joka itse oli Granön oppilas ja läsnä 1920luvun maantieteen laitoksen toiminnassa, on maininnut termit voor, mõhn, vallseljak, rannarõõne, ürgorg, mannerjää, sälkorg, orglaht, silmusjärv, murdkulbas, paguvesi, paisjärv, puisniit, sumbküla, kultuurmaistu, vakla (lähestikule vastav, kindlalt piiratud, ümbrusnähtuste poolest iseloomustatud ala), paigastik (maastikule vastav, kaugnähistiku poolest iseloomustatud maa-ala) (Kant 1956: 261). Taloustieteilijä Uno Mereste esittää Granön luomiksi tai täsmentämiksi termit lähi- ja kaugkeskkond, lähestik, maastik, geograafiline indiviid (Mereste 1985: 182). Taavi Pae on kirjoittanut tarkemmin termin puisniit alkuperästä ja olettanut sen todennäköisesti Granön luomaksi (Pae 2010).

2 Granön ajan termistö on artikkelissamme esitetty alkuperäisessä asussa joko viroksi tai suomeksi. Emme ole kääntäneet termejä, koska vastaavia termipareja ei ole. Kääntämisen sijaan joutuisimme esittämään kuvailevia selityksiä. Termiesimerkit havainnollistavat Granön ajan kieltä ja termistön rakennetta. 
Asta Veski on analysoinut maantieteen termistön lautakunnan työn tuloksia ja laskenut, että vuonna 1929 julkaistun geologian termistön sanastossa Valik saksa- ja eestikeelseid geoloogilisi oskussõnu (Granö 192-?) on noin 175 uudissanaa $^{3}$. Uusien termien luomiseen käytettiin pääasiallisesti johtamista mutta myös yhdyssanojen muodostamista. Johtimista yleisimpiä ovat -us, -is ja -mine; muita johtimia on käytetty vain muutamia kertoja (Veski, A. 1996: 111). A. Veski viittaa myös kyseisen lautakunnan julkaisemattomaan sanastoaineistoon, mutta hän ei valitettavasti anna siitä tarkempia lähteitä. Huomiomme kiinnittyi kuitenkin siihen, että julkaisemattoman aineiston termien luomisessa on suosittu erilaisia johtimia: eniten on käytetty johdinta -kond, seuraavaksi - $i k$ ja huomattava määrä myös -istu-, -mik- ja $-k$-johtimia.

Tämäkin on erikoinen historiallinen sattuma, että Granön johtaman maantieteen termistön lautakunnan työstä saa oman erillisen julkaisunsa geologian sanasto muttei maantieteen.

Granön kehittämää vironkielistä termistöä ei löydy kokonaisuutena mistään lähteestä. Toisin on suomen kielen osalta, sillä Granö esitti teoksessa Puhdas maantiede käsitteiden järjestelmän termeineen. Valitettavasti myöskään Tarton yliopistossa toimineen maantieteen termistön lautakunnan pöytäkirjoja ei ole säilynyt. Tallessa on ainoastaan yksi käsin kirjoitettu sanalista (ks. alaviite 3). Granön Virossa tehtyä termistötyötä kuvaa ehkä parhaiten teos Tartumaa: maadeteadusline, majandusline ja ajalooline kirjeldus (1925), jonka päätoimittaja oli Jaan Rumma. Toimituskuntaan kuuluivat myös Granö ja J. V. Veski. Teoksen sanaluettelossa on selitetty yhteensä 122 sanaa. Termistön järjestelmällisyys on suorastaan kaunista. Käsiteltävä alue (Tarton maakunta) oli kuvauskohteena hyvin rajattavissa, eikä aihealueita ole liian paljon. Seuraavaksi käsittelemme muutamia esimerkkejä.

$3 \quad$ Asta Veski (1996) ei artikkelissaan määrittele, mikä on uudissana. Vuoden 1929 sanastossa noin 90 prosenttia on termejä, jotka eivät esiinny vuoden 1911 sanastossa. Veski ei kuitenkaan tarkenna, millä perusteella hän katsoo uudissanoiksi vain murtoosan. 
"ajattele maailmanlaajuisesti, toimi paikallisesti" ( J. g. granö)

Granön maisemamaantieteen termistö perustuu uuteen ajatukseen, että kaupunki tai muu asutus on myös osa luonnonmaisemaa. Ajatus näkyy vahvasti termistössä, sillä maisemamaantieteen termistö käsittää maaston lisäksi erilaisten asutusten ja rakennusten muotoja, varsinkin erimuotoisia kattoja on kuvattu tarkkaan, esimerkiksi jässikpoolkelpkatus, kelbaskatus, kelpkatus, kelpmurdkatus, leepkelbaline katus, leepviilune katus, lõikkelpkatus, madal poolkelbaline katus, madalaviiluline katus, mansardkatus, poolkelpkatus, terravviiluline katus, varjukatus, viilkatus, viilmurdkatus (15 kpl). Katujärjestelmien termit ovat erittäin kuvaavia: kodartänavastik 'tänavad, kus ükiskud tänavad lõikuvad nurgi teatavas keskkohas', malelaudtänavastik, püstküliktänavastik, radiaaltänavastik, ruut-tänavastik.

Granö suosi termistössä yhdyssanoja, sillä noin 40 prosenttia termeistä on yhdyssanoja. Tämä on ymmärrettävä, koska yhdyssanan edusosa varmistaa, että puhutaan samasta käsitteestä ja kuvaava sana tarkentaa ja kuvaa silmiinpistävän ominaisuuden kautta käsitettä. Termien järjestelmällisyyttä kuvaavat esimerkiksi Granöön liittyvistä töistä (Rumma ym. 1925; Kant 1926; Vilberg 1921 ja 192? käsin kirjoitettu sanalista) - org- 'laakso' ja -maa-loppuiset yhdyssanat. Valitsimme ne esimerkeiksi, koska ne kuvaavat Viron keskeisiä maastomuotoja. Laaksoja kuvaavat sanat ovat seuraavat: kalde-kõrglammorg, kuruorg, lammorg, liudorg, moldorg, ripporg, sälkorg, uhtorg, ürgorg. -maa-loppuiset yhdyssanat ovat seuraavat: jäätmaa 'mahajäetud söödis ja metsastunud põld', lausmaa, raadikmaa, tulemaa 'koht, kus keedetakse väljas lageda taeva all', vahemaa 'randjärvede vahel olev körgem seljak (Viinistul)'.

Johdoksia on lähes yhtä paljon kuin yhdyssanoja. Johdosten käyttö antaa läpinäkyvän mahdollisuuden hahmottaa termistön hierarkiaa, kuten ylä- ja alakäsitteitä. Johtimista suosittuja ovat esimerkiksi -ik ja -stik. Johdosten joukossa on sekä murresanoja että uusia luomuksia, joista osa on muodostettu omaperäisistä kantasanoista, osa lainasanoista. Esimerkiksi kõrgendik, rannik 'sooveer', järvik 'väike järv', kurmik 'kurmuga hoone', kõvik, rahnik, sõõrik 'sõõrisarnase põhisega hoone', sabrik, laadik 'kastike, sahtel'. Sanan rannik merkitys on nykykielessä 
laajentunut suon reunaman merkityksestä meren ja mantereen rantaalueen merkitykseksi. Termi laadik on varsin läpinäkyvä laina suomesta - ilmeisesti Aavikin luomus (Aavik 1921).

-stik-johtimella on kaksi merkitystä: paikka ja kollektiivi, ja yleensä nämä kaksi merkitystä esiintyvät samanaikaisesti (Kasik 2009: 124). Kyseinen johdin oli jo hyvin ahkerassa käytössä vuonna 1911 ilmestyneessä Maateaduse sõnastik -sanastossa. Niitä on yhteensä 13 kappaletta: saarestik, kuristik, taimestik, mägestik, rägastik, jääliugustik, küngastik, lõhestik, mäelõhestik, puiestik (park), kärestik, ilmastik, maastik (maakoht), loomastik. Esimerkiksi sana maastik ei varsinaisesti ole Granön keksimä, mutta hän on määritellyt sen maisemamaantieteen termiksi. Teoksessa Eesti maastikulised üksused kirjoittaa Granö maastik-termistä seuraavasti: "[---] maastik on teatav maapinna osa, regionaalne üksus, kus inimene võib esineda vähemalt ajutise vaatlejana, kus horisont esineb, ning millel teatud, iseloomustavad, alalised või perioodiliselt vahelduvad, maastikuliselt esinevad ja järelikult nägemise läbi defineeritavad omadused." ${ }^{3}$ Alahuomautukseen Granö on lisännyt: "Ehk küll maastikust geograafilise üksusena on palju kirjutatud, ei ole minu teada seda mõistet seni katsutud ära määrata. Sõna maastik ei ole aga nii selge, et täppis määrang oleks ülearune."5 (Granö 1922: 2).

Granö pyrki luomaan mahdollisimman yksiselitteisesti kuvaava termistöä ja käytti termien kantoina tuttuja muotojen nimityksiä. Vironkielisessä termistössä hän on käyttänyt esimerkiksi astioiden nimityksiä painaumia kuvaavina termeinä: häil (murresana 'kattila') 'katlataoline järsuveereline sulglohk', kauss 'ümmargune sulglohk, kus põhja ja veerude vahel järsk nurk', lehter 'lehtritaoline terava põhjaga ümmargune

\footnotetext{
4 Maisema on tietynlainen maanpinnan osa, alueellinen yksikkö, jossa ihminen voi olla ainakin väliaikaisena tarkkailijana, jossa on aina horisontti ja jolla on tietyt luonteenomaiset, pysyvät tai ajoittain vaihtelevat maisemallisesti esiintyvät eli katsomalla määriteltävät ominaisuudet (suom. E. M.).

5 Vaikka maastosta on kirjoitettu maantieteellisenä yksikkönä paljon, käsitteenä sitä ei ole yritetty määritellä. Sana maastik ei kuitenkaan ole niin selkeä, että sen tarkka määritteleminen olisi turhaa (suom. E. M.).
} 
"ajattele maAilmanlaajuisesti, tolmi paikallisesti" (J. g. granö)

sulglohk', liud 'ümmarguse põhijoonisega sulglohk, kus veerude ja põhja vahel puudub märgatav lohk', mold 'piklik sulglohk, kus põhi märgatamata veerudeks üle läheb’.

Maantieteen termistön lisäksi Granö on luonut joukon Viron paikannimiä alueille, joita hän kuvasi: Pärnumaalla Soomaa ja Sootaguse, Pohjois-Virossa Lahemaa, Pohjois-Tarttomaalla Vooremaa, Petserinmaalla Palumaa (Kurs 1995: 1065).

\section{J. G. Granön maantieteen termistötyö Suomessa}

Granö palasi Tartosta Suomeen 1922. Maantieteen yliopisto-opetus ja tutkimus olivat päässeet Virossa hyvään alkuun, ja Granön työlle oli Tartossa osaavia jatkajia. Heti Suomeen palattuaan Granö jatkoi Virossa aloittamaansa sanastotyötä - mutta suomeksi. Ensin Granö alkoi koota suomenkielistä maisemamaantieteen sanastoa. Vuonna 1923 perustetussa sanastovaliokunnassa olivat mukana Väinö Auer, Matti Sauramo ja kielitieteilijä Y. H. Toivonen. Sanastovaliokunnan tavoitteena oli määritellä olemassa oleva yleiskielen sanasto maisemamaantieteen kannalta täsmällisemmin. Periaate on sama kuin vironkielisen termistön kehittämisessä. Tarkemmin määriteltyjä yleiskielen sanoja olivat esimerkiksi tekijä, muoto, jono, laakso, vesi, joki, sade ja pilvi. Lisäksi Granö ja Toivonen loivat uudissanoja. Sanaston koostamisen periaatteita Toivonen kuvaa seuraavasti: "[---] on koetettu tavoitella selvyyttä, täsmällisyyttä ja myöskin lyhyyttä”. He pyrkivät käyttämään mahdollisimman paljon suomen kielen omia sanavaroja ja jopa murteellisia sanoja. Jos oma sanavarasto ei riittänyt, Granö ja Toivonen muodostivat uusia johdoksia, yhdyssanoja ja kuvaannollisia nimityksiä. Nämäkin lähtökohdat ovat hyvin samanlaisia kuin Virossa. Huomionarvoinen on myös periaate, ettei kaikkia tieteellisiä nimityksiä käännetty (esimerkiksi atolli ja firni). (Toivonen 1924: 37-38.) Granö julkaisi sanaston vuoden 1924 Terrassa. Siinä Granö (1924: 1) kirjoittaa, ettei 1912 julkaistu Maantieteilijäin saksalais-suomalainen sanasto riittänyt alkuunkaan maisemamaantieteen yliopisto-opetuksen tarpeisiin. Erityisesti teorian mutta myös termistön 
kehittämistä Granö jatkoi myös vuoden 1924 jälkeen ja lopullinen teoria on julkaistu teoksena Puhdas maantiede (1930).

Seuraavaksi teemme havaintoja Puhtaan maantieteen sanastosta ${ }^{6}$, koska sitä pidetään Granön teoreettisena päätyönä, jossa Granö yhdistää sekä Suomessa että Virossa tekemäänsä tutkimusta ja rakentaa luomastaan termistöstä kokonaisuuden. Yhteensä termejä on noin 300. Samoin kuin Granön vuonna 1924 julkaisemassa Terran sanastossa, Puhtaan maantieteen ydinsanaston muodostavat yleiskielestä tutut maisemaa ja maanpinnanmuotoja kuvaavat sanat. Granön erikoissanastosta osa on ikivanhoja perussanoja, esimerkiksi joki, koski ja kymi. Osa vanhasta sanastosta on myös ikivanhoja lainoja, kuten harja, lahti ja meri. Tällainen yleiskielen perussanasto märiitellään Granön luokittelussa yleiskielen merkityksiä tarkemmin osaksi käsitejärjestelmää. Osa perussanoista on yleiskielessä harvinaisia mutta tavallisia jossakin suomen murteessa, esimerkiksi jolma, kero, luusua, niva, orko ja vuo. Yleiskielestä tai murteista saatu perussanasto muodostaa merkittävän osan Granön termistöä, noin 30 prosenttia kaikista termeistä. Se on luonnollista siksi, että kielessä on aina tarvittu maisemaa ja maastoa kuvaavaa sanastoa. Granö on tietoisesti valinnut ja määritellyt tämän sanaston osaksi termistöä. Myös osa Granön käyttämistä johdoksista on joko vanhoja yleiskielen sanoja tai tuttuja ainakin joistakin suomen murteista.

Johdoksista, yhdyssanoista ja sanaliitoista Granön sanastossa on eniten yhdyssanoja (melkein 50 \%) mutta myös johdoksia on melko paljon (33 \%). Granö käyttää yleiskielessäkin tavallisia kollektiivijohtimia, esimerkiksi aallokko, allikko, jäkälistö, levästö, vesistö, virrasto. Granön termistössä näillä on yleiskieltä tarkempi ryhmämuodon merkitys. Muita tavallisia johtimia ovat esimerkiksi teon tulosten nimet ilmentymä, kaartama ja johdokset ylänkö ja tasanko, jyrkkiö, lähiö, harjanne, kulpanne, kohdake, lahdeke, seuduke. Tyypillisesti Granön sanaston termit

$6 \quad$ Analyysi pohjautuu Päivi Laineen pro gradu- tutkielmassa esittämään analyysiin ja vertailuun (ks. Peltonen 1998). Laineen väitöskirja puolestaan tarkastelee maantieteen suomenkielisen termistön kehittämistä ennen Granön aikaa, 1800-luvulla (ks. Laine 2007). 
"ajattele maAilmanlaajuisesti, toimi paikallisesti" ( J. g. granö)

ovat yhdyssanoja, esimerkiksi avolähiö, avomaisema, avomuoto, avonäkymä, avorannikko, avoympäre tai ilmentymäala, ilmentymäalue, ilmentymäryöhyke. Yhdyssanat rakentavat siis läpinäkyvää, osista pääteltävää taksonomiaa ja ovat siksi olennainen osa termistöä. Huomionarvoista on, että Granön käsitejärjestelmä rakentuu näissä esimerkeissä yhdyssanojen määriteosista. Tällaista termien rakentamista hänellä ei ollut vielä Virossa. Viisi prosenttia vastaavasta termistöstä on Granöllä myös sanaliittoja, esimerkiksi suojattu rannikko tai suihkun allikko. Vaikka Granö käyttää erikoissanastonsa runkona yleiskielen ja murteiden sanastoa, johtamalla ja yhdistämällä muodostetut termit ovat Granön sanastossa keskeisiä uudissanoja.

Granö on kehittänyt suomenkielistä maantieteen termistöä pitkäjänteisesti sekä työryhmässä että itsenäisesti. Siksi suurin osa eli jopa noin 70 prosenttia Puhtaan maantieteen sanastosta on 1800-luvun lopun tai 1900-luvun alun uudissanastoa ${ }^{7}$. Näistä osa on Granön ajan tai Granön uudissanoja. Johdoksista tällaisia ovat todennäköisesti korkeikko, kulpanne, laakio, lahdisto, laskeuma, lähiö, putaisto, syviö ja ylhiö. Granön tai hänen johtamansa sanastovaliokunnan uudisyhdyssanoja ovat todennäköisesti edellä kuvattujen avo- ja ilmentymä-alkuisten yhdyssanojen lisäksi esimerkiksi sanat aistiympäristö, allasmaa, kaukoilmentymä, kuurnalaakso, laakarannikko, pensastomaisema, pystyrannikko, saaristorannikko, sirppiharja, tekomaisema ja törmärannikko. Näistä monet eivät ole kuitenkaan vakiintuneet maantieteen erikoiskielen käyttöön. Huomionarvoista on myös, ettei Granö käyttänyt termistössään juurikaan vierassanoja, vaan termistö on pyritty tietoisesti rakentamaan omaperäisistä aineksista; Puhtaassa maantieteessä on vain viisi vierassanaa: disharmoninen, harmoninen, mediumi, substanssi ja substraatti. Näissäkin kyse on yleisistä eri aloille yhteisistä vierassanoista.

Uudissanojen todellista ikää pitäisi selvittää kirjallisista lähteistä tätä artikkelia tarkemmin. Nyt karkea arvioi on tehty Suomen murteiden sanakirjan (SMS) ja etymologisen sanakirjan avulla (SSA). 


\section{Lopuksi}

Maantieteen sanastotyö toimii artikkelissamme esimerkkinä siitä, miten eri alojen termistöä alettiin Virossa kehittää. Koska tieteenalan termistöä kehittivät kielitieteilijöiden lisäksi maantieteen asiantuntijat, vastaava tilanne voisi Virossa olla myös muilla aloilla, esimerkiksi matematiikassa ja kansatieteessä, mutta muiden alojen sanastoista ei ole vielä tutkimusta. Eri alojen termistöjen kehittäjissä riittäisikin Virossa vielä selvitettävää, sillä J. V. Veskin osuus ei ehkä olekaan niin valtava kuin aiemmin on uskottu.

Toinen keskeinen huomiomme on, että Virossa vaikuttanut kielen uudistaminen heijastui myös Suomeen. Kyse ei ollut pelkästään vaikutteiden hakemisesta aiemmasta suomen kielen kehitystyöstä. Granön jättämä jälki termistöjen luomisessa on konkreettinen esimerkki Viron vaikutteista suomen kirjakielen kehitykseen. Hän toi suomalaisen sanastolautakunnan työskentelyyn samat periaatteet, joita ammattisanaston luomisessa oli käytetty Virossa. Sanoja ei voinut suoraan siirtää kielestä toiseen, mutta läheisten sukukielten termistöjä voitiin luoda samanlaisten sananmuodostuskeinojen avulla. Erityisesti tämä näkyy melko samanlaistenkin johdinten käytössä (esimerkiksi -ik ja -(i)kko) ja kuvailevan sanaston suosimisena, kuten kuhmu, sirppiharja, kodartänavastik ja moldorg.

Lopuksi haluamme palata Granön toimintaperiaatteeseen "ajattele maailmanlaajuisesti, toimi paikallisesti". Nykyajan (tiede)maailmassa englanti on sivuuttanut suurten perinteisten tieteen kielten (saksa ja ranska) lisäksi lähestulkoon kaikki kansalliset kielet. Mitään tärkeää ei enää julkaista omalla kansallisella kielellä. Kun kehitettyjä alan termejä ei käytetä, niiden merkitykset unohtuvat ja termit muuttuvat tarpeettomiksi. Tuskin yksikään 1900-luvun alussa toiminut viron tai suomen kielen kehittäjä olisi uskonut, että sadan vuoden päästä oman äidinkielen korkeatasoisesta käytöstä luovutaan vapaaehtoisesti ja muistamatta sitä, millä työmäärällä, innolla ja aatteilla kansalliset tiedekielet on aikoinaan luotu. 
"ajattele maAilmanlaajuisesti, tolmi paikallisesti" (J. g. granö)

\section{Lähteet}

Aavik, Johannes 1921. Uute sõnade ja vähem tuntud sõnade sõnastik. Tallinn: A. Keisermann.

Erelt, Tiiu 2002. Eesti Keelekorraldus. Tallinn: Eesti Keele Sihtasutus.

Granö, J[ohannes] G[abriel] 1920. Geograafia kui teadus ja ülikooli aine. Tartu: Postimees.

Granö, J[ohannes] G[abriel] 1922. Eesti maastikulised üksused. Tartu: K. Mattiiseni trükk.

Granö, J[ohannes] G[abriel] 1924. Maisemamaantieteen tehtävät ja maiseman muotojen järjestelmä. - Terra, 1-36.

Granö, J[ohannes] G[abriel] 1930. Puhdas maantiede. Tutkimusesimerkeillä Suomesta ja Virosta valaistu metodologinen selvitys. Porvoo: WSOY.

Hakulinen, Lauri 1979. Suomen kielen rakenne ja kehitys. 4. painos. Helsinki: Otava.

Häkkinen, Kaisa 1994. Agricolasta nykykieleen. Suomen kirjakielen historia. Porvoo: Werner Söderström Osakeyhtiö.

Kant, Edgar 1926. Tartu: linn kui ümbrus ja organism: linnageograafiline vaatlus, ühtlasi lisang kultuurmaastiku morfoloogiale. Tartu.

Kant, Edgar 1956. Johannes G. Granö mälestuskilde eesti maateaduse ja koduuurimise rajajast. - Tulimuld, 254-260.

Kasik, Reet 2009. Eesti keele sõnatuletus. Kolmas, parandatud trükk. Tartu: Tartu Ülikooli Kirjastus.

Kask, Arnold 1938. J. V. Veski ja eesti oskussõnastikud. - Eesti Keel 17 (3-5), 65-91.

Kask, Arnold 1970. Eesti kirjakeele ajaloost II. Tartu: Tartu Riiklik Ülikool.

Kolehmainen, Taru 2014. Kielenhuollon juurilla. Suomen kielen ohjailun historiaa. Suomi 204. Kotimaisten kielten keskuksen julkaisuja 174. Helsinki: Suomalaisen Kirjallisuuden Seura ja Kotimaisten kielten keskus.

Kurs, Ott 1995. Johannes Gabriel Granö Eestis. - Akadeemia 5, 1057-1077.

Laine, Päivi 2007. Suomi tiellä sivistyskieleksi. Suomenkielisen maantieteen sanaston kehittyminen ja kehittäminen 1800-luvulla. Väitöskirja. Suomalaisen ja yleisen kielitieteen laitoksen julkaisuja 77. Turku: Turun yliopisto.

Maantieteilijäin saksalais-suomalainen sanasto. Laatinut Suomen maantieteellisen yhdistyksen asettama toimituskunta. Helsinki, 1912.

Mereste, Uno 1985. Johannes Gabriel Granö ja teoreettinen maantiede. - Terra 97 (3), 176-183. 
Nordlund, Taru 2004. Arat taimet ja ankarat puutarhurit. 1800-luvun lopun kielikeskustelun metaforat ja kieli-ideologiat. - Katja Huumo, Lea Laitinen, Outi Paloposki (Toim.), Yhteistä kieltä tekemässä. Näkökulmia suomen kirjakielen kehitykseen 1800-luvulla. SKS:n toimituksia 979. Helsinki: Suomalaisen Kirjallisuuden Seura, 286-322.

Pae, Taavi 2010. Kust pärineb sõna puisniit? - Eesti Loodus 11, 39-41.

Paunonen, Heikki 1989. Muuttuvat puhesuomen muodot. - Seija Aalto, Auli Hakulinen, Klaus Laalo, Pentti Leino, Anneli Lieko (Toim.), Kielestä kiinni. Tietolipas 113. Helsinki: Suomalaisen Kirjallisuuden Seura, 209-233.

Peegel, Juhan 1963. J. V. Veski 90-aastane. - Emakeele Seltsi aastaraamat 9, 3-6.

Peltonen, Päivi 1998. Luonnonmaantieteen suomenkielisen termistön muotoutuminen ja vakiintuminen. Pro gradu -tutkielma. Turku: Turun yliopisto suomalaisen ja yleisen kielitieteen laitos.

Pokela, Kristiina 2004. Virittäjä kielenohjailun suunnannäyttäjänä. - Eija Kalliokoski, Kristiina Pokela (Toim.), Puristien suomesta moniarvoiseen kieleen. Oikeakielisyyden, kielenohjailun ja -huollon periaatteita ja käytäntöä nykysuomen alusta kolmannelle vuosituhannelle. Vaasa: Vaasan yliopiston julkaisuja, 13-130.

Pulkkinen, Paavo 1972. Nykysuomen kehitys. Tietolipas 72. Helsinki: Suomalaisen Kirjallisuuden Seura.

Raag, Raimo 2008. Talurahva keelest riigikeeleks. Tartu: Atlex.

Rikkinen, Hannele 1980. Maantieteen asema ja sisällön kehitys Suomen oppikouluissa 1500-1770. - Terra 92 (2), 88-105.

Rintala, Päivi 2000. Oikeakielisyydestä kielenhuoltoon. - Kielikello 1, 19-23.

Rumma, Jaan, Johannes Gabriel Granö, Johannes Voldemar Veski 1925. Tartumaa: maadeteadusline, majandusline ja ajalooline kirjeldus. Tartu: Eesti Kirjanduse Selts.

Saareste, Andrus 1938. Eesti keele mitmest palgest. Akadeemilise Emakeele Seltsi toimetised 36. Tartu: Akadeemiline Emakeele Selts.

Saareste, Andrus 1951. Üksiku ja üldsuse osast keeleelus. - Henno Jänes (Toim.), Pühendusteos Johannes Aavikule 70. sünnipäeva puhul 8. detsembril 1950. Lund, 47-57.

SMS = Suomen murteiden sanakirja. Kotimaisten kielten keskuksen julkaisuja 36. Helsinki: Kotimaisten kielten keskus, Suomalaisen Kirjallisuuden Seura, 1985-2008.

SSA = Suomen sanojen alkuperä. Etymologinen sanakirja. SKS:n toimituksia 556. Helsinki: Suomalaisen Kirjallisuuden Seura, 1992-2000. 
"ajattele maailmanlaajuisesti, toimi paikallisesti" (j. g. granö)

Tammekann, August 1932. Prof. J. G. Granö 50-ne aastane. - Loodusevaatleja, 33-35.

Tiitta, Allan 2011. Sinisten maisemien mies. J. G. Granön tutkijantie 1882-1956. Historiallisia tutkimuksia 256. Helsinki: Suomalaisen Kirjallisuuden Seura.

Toivonen, Y[rjö] H[enrik] 1924. Suomenkielisestä maisematieteellisestä sanastosta. - Terra, 37-41.

Tommila, Päiviö 2012. Johannes Gabriel Granö, tutkimusmatkailija ja kolmen yliopiston professori. - Historiallinen aikakauskirja 110 (4), 473-476.

Veski, Asta 1996. Geoloogia ja geograafia terminoloogia XX sajandi I poolel. Emakeele Seltsi aastaraamat 35-42 (1989-1996), 109-114.

Vilberg, Gustav 1921. Harjumaa. Maateadusline lugemik. Tartu: Loodus.

Vilberg, Gustav 192-?. Valik geoloogilisi ja geograafilisi oskussõnu. Käsikirja paljundatud koopia Endel Varepi arhiivis Tartu Ülikooli geograafia osakonnas.

\section{Päivi Laine}

Turun yliopiston kieli- ja käännöstieteiden laitos

Suomen kieli ja suomalais-ugrilainen kielentutkimus

20014 Turun yliopisto, Finland

paipel@utu.fi

\section{Eve Mikone}

Turun yliopiston kieli- ja käännöstieteiden laitos

Suomen kieli ja suomalais-ugrilainen kielentutkimus

20014 Turun yliopisto, Finland

eve.mikone@utu.fi 


\title{
Development of geographical terms in Estonia and Finland in the 1920s
}

\author{
PÄIVI LAINE, EVE MIKONE \\ University of Turku
}

Our article deals with the development of geographical terms in Estonia and in Finland during the 1920's. This period is especially interesting because the language of instruction in the respective countries changed to Estonian and to Finnish at roughly the same time. The development of scientific terminology in different fields was started on both sides at the same time as well. The Finnish geographer Johannes Gabriel Granö went to Tartu in 1919 to establish a Department of Geography at the University of Tartu. He was the first person to teach geography in Estonian and he needed a vast amount of professional terminology. Previously the teaching languages were German and Russian. During his short stay (3 years), J. G. Granö started developing geographical terminology in Estonian. At the same time, he also made efforts to consolidate the use of new scientific terminology. J. G. Granö established the committee of geographic terminology at Tartu University, but he never published any research in Estonian. The results of J. G. Granö's work can be found in the different areal studies of Estonia. The main editors of these books were J. G. Granö's students. The study of the development of Estonian scientific terminology postulates that nearly all new scientific terms were invented by J. V. Veski. We assume that his role was in many areas primarily consulting, not inventing. Many of J. G. Granö’s invented terms are nowadays very common, such as ürgorg, voor, and vallseljak; even many Estonian place names (Soomaa, Lahemaa, Vooremaa) were likely invented by J. G. Granö. Back in Finland, J. G. Granö continued his work on geographical terminology in Finnish. His main theoretical study, Pure Geography (1930), brings together the theoretical basis which was developed in Estonia and practical work done in Finland. J. G. Granö highlighted the importance of doing science in national languages and reporting results in international languages.

Keywords: terminology; geography; national language; Estonian; Finnish 